\title{
17. LATE QUATERNARY STABLE ISOTOPE RECORD OF PLANKTONIC AND BENTHIC FORAMINIFERS: SITE 861, CHILE TRIPLE JUNCTION, SOUTHEASTERN PACIFIC ${ }^{1}$
}

\author{
J. Schönfeld, ${ }^{2}$ D. Spiegler, ${ }^{2}$ and H. Erlenkeuser ${ }^{3}$
}

\begin{abstract}
Stable carbon and oxygen isotopes were analyzed from Globigerina bulloides, Globoconella inflata, and Cibicidoides wuellerstorfi in upper Quaternary sediments from ODP Holes $861 \mathrm{~A}$ through $861 \mathrm{C}$. They are located in $1652 \mathrm{~m}$ water depth off the coast of southern Chile at $45^{\circ} 51^{\prime} \mathrm{S}, 75^{\circ} 41.5^{\prime} \mathrm{W}$. The correlation of the oxygen isotope curves with the SPECMAP stack reveals that the record of the uppermost 80 mbsf goes back to oxygen isotope Event 10.2, which is 341 k.y. before the present. Linear sedimentation rates show strong variations and are highest during Terminations I and II, and in the lithostratigraphic Subunit II, where debris flows and sand turbidites occur. Ice-rafted debris was only recorded in four distinct intervals that occur in glacial intervals. Discrepancies between sea-surface paleotemperatures as estimated from oxygen isotopes and occurrences of subtropical planktonic foraminifers reveal the sporadic influence of warm surface waters, driven southward to at least $46^{\circ} \mathrm{S}$ by El Niño at the end of Termination Ia. This warm-water influence is corroborated by silicoflagellate assemblages and by the history of the Cordilleran glaciers in southern Chile.
\end{abstract}

\section{INTRODUCTION}

\section{Geological Setting}

Site 861 is located in $1652 \mathrm{~m}$ water depth, midway on the continental slope off the coast of southern Chile at $45^{\circ} 51^{\prime} \mathrm{S}$ and $75^{\circ} 41.53^{\prime} \mathrm{W}$ (Fig. 1). In the upper part of the section down to $43.8 \mathrm{~m}$ below seafloor (mbsf), the sediments comprise silty clays to clayey silts (Subunit I). Many diamictites, which are interpreted as debris flows, a few turbiditic sand layers, and some volcanic ash beds are intercalated in the section interval below 43.8 mbsf (Subunit II; Shipboard Scientific Party, 1992).

\section{Stratigraphy}

The few biostratigraphic datum levels allow the development of only a coarse age model for Site 861 (Shipboard Scientific Party, 1992). The uppermost 129 mbsf of the succession shows a relative uniform sedimentation rate of $26 \mathrm{~cm} / \mathrm{k} . \mathrm{y}$. The oxygen isotope stratigraphy is therefore applied to obtain additional age-control points, that will allow further refinement of the chronostratigraphy at Site 861 .

\section{Hydrography}

Documenting Pleistocene climatic changes off the coast of southern Chile will be an important step toward understanding climatic variability in South America. Today, the climate of southern Chile is largely influenced by the surface waters of the southeastern Pacific. Generally, the surface water is coming from the west as part of the Antarctic Circumpolar Current (Pickard and Emery, 1993). The surface current divides at $39^{\circ}-40^{\circ} \mathrm{S}$ into two branches (Boltovskoy, 1976). One of these flows to the south and joins the Cape Horn Current. The other branch turns northward to form the Peru Current, which transports cold, nutrient-rich water northward up to $15^{\circ} \mathrm{S}$. The Peru Current is bounded to the northwest by the Subtropical Convergence which separates the temperate waters of the Antarctic Circumpolar Current from the warm South Pacific Subtropical Gyre (Fig. 1).

\footnotetext{
'Lewis, S.D., Behrmann, J.H., Musgrave, R.J., and Cande, S.C. (Eds.), 1995. Proc. ODP, Sci. Results, 141: College Station, TX (Ocean Drilling Program).

2 GEOMAR Research Center for Marine Geosciences, Wischhofstrasse 1-3, D-24148 Kiel, Federal Republic of Germany.

${ }^{3}$ C14-Laboratory, Institute for Nuclear Physics, University of Kiel, Leibnizstrasse 19. D-24098 Kiel, Federal Republic of Germany.
}

The position of the Subtropical Convergence shows strong seasonal changes. In January, it is centered at $40^{\circ} \mathrm{S}$, turns to the northeast at $90^{\circ} \mathrm{W}$, and proceeds eastward to $80^{\circ} \mathrm{W}$. The Subtropical Convergence retreats in July to $35^{\circ} \mathrm{S}$ and the eastern flank roughly parallels the $90^{\circ} \mathrm{W}$ meridian (Couper, 1989).

Although surface temperatures of $9^{\circ}$ to $13^{\circ} \mathrm{C}$ prevail off the coast of Chile today, planktonic foraminifers indicative of warmer water were found in upper Pleistocene sediments recovered from Ocean Drilling Program (ODP) Leg 141. The warm-water species were even recorded at Site 862 , which is located at $46^{\circ} 31^{\prime} \mathrm{S}$ (Spiegler and Müller, this volume). As such, this region may have been under the influence of the warm-water sphere during the late Pleistocene or early Holocene.

\section{MATERIAL AND METHODS}

We analyzed the stable oxygen isotopes of the near-surface living planktonic foraminifer Globigerina bulloides to corroborate the results from the foraminifer study at Site 861 , which has the most complete Pleistocene succession of the Leg 141 sites. The deeper dwelling Globoconella inflata and the benthic species Cibicidoides wuellerstorfi were also analyzed to discern isotopic fluctuations in near-surface waters from the global signal.

The same shipboard taken samples were used for the planktonic and benthic foraminifer studies. The spacing of the samples is $1.87 \mathrm{~m}$ on average. Additional samples from the uppermost 40 mbsf have been requested in order to improve the resolution of our data set. For the present study, only samples from the uppermost $80 \mathrm{mbsf}$ of Site 861 were used because of the poor core recovery below. Holes $861 \mathrm{~A}$, $861 \mathrm{~B}$, and $861 \mathrm{C}$ were combined to form a composite succession by correlating the demagnetized intensity records (Shipboard Scientific Party, 1992). At Holes 861B and 861C, the composite depth of a sample interval is closely approximately the depth in the core. At Hole $861 \mathrm{~A}$, however, the core depth is $5.60 \mathrm{~m}$ lower than the composite depth for a sample interval.

The samples were washed over a $63-\mu m-m e s h$ screen and dried, and the foraminiferal tests were picked from the $>180 \mu \mathrm{m}$ grain-size fraction. Only well preserved specimens were separated, which were free of corrosion, overgrowth, and chambers filled with fine-grained sediment or pyrite. We used 10 to 20 tests of each, G. bulloides and $G$. inflata. For the benthic record, 2 to 5 tests of $C$. wuellerstorfi were separated. Isotope analyses were made with the automated Carbo Kiel $\mathrm{CO}_{2}$ preparation-device coupled to a Finnigan MAT 251 mass spec- 


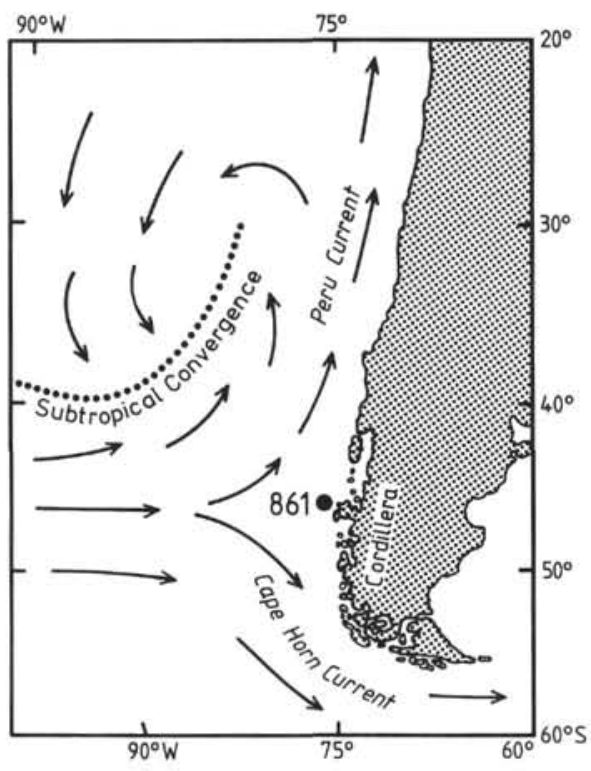

Figure 1. Location map.

trometer at the C14-Laboratory, Kiel University. The isotope ratios are expressed in the usual $\delta$-notation in per mil relative to the PDB standard (Craig, 1957). The external accuracy of the measurements amounts to $\pm 0.08 \%$ and $\pm 0.04 \%$ for $\delta^{18} \mathrm{O}$ and $\delta^{13} \mathrm{C}$ values, respectively.

We applied the oxygen isotope stratigraphy as a chronostratigraphic tool to develop an age model and to calculate sedimentation rates. A detailed taxonomy of isotopic fluctuations has been established by Pisias et al. (1984) and Prell et al. (1986). Oxygen isotope events were identified by graphic correlation with the SPECMAP stack as indicated on Figure 2. Their absolute ages were estimated by orbital tuning with an accuracy of approximately $\pm 5000 \mathrm{yr}$ (Imbrie et al., 1984).

The beginning of Termination Ia and $\mathrm{Ib}$ and the end of Termination $\mathrm{Ib}$ are also recognized though with some uncertainty because of insufficient sample spacing. The age of these events was determined in sediment cores from the Atlantic by traditional and accelerator mass spectrometer (AMS) ${ }^{14} \mathrm{C}$ analyses with an accuracy of $\pm 100 \mathrm{yr}$ (Duplessy et al., 1986; Bard et al., 1987; Broecker et al., 1988). The respective calendar years were taken from Sarnthein and Tiedemann (1990) and Sarnthein et al. (1994). The oxygen isotope events and their ages, as considered in this paper, are given in Table 1.

The occurrence of coarse lithic grains was recorded in addition to quantify the input of ice-rafted debris. The grain-size fraction $>500$ $\mu \mathrm{m}$ was examined under the binocular microscope. Lithic and biogenic particles were counted and diagenetic aggregates, mainly pyritized burrows, were discarded.

The portion of lithic grains is expressed in percent of the total nondiagenetic fraction (i.e., lithic and biogenic particles; Table 2).

Paleotemperatures were calculated from the oxygen isotope composition of foraminiferal tests by using the following equation (Craig, 1965):

$$
T=16.9-4.2\left(\delta_{\mathrm{C}}-\delta_{\mathrm{w}}\right)+0.13\left(\delta_{\mathrm{C}}-\delta_{\mathrm{w}}\right)^{2},
$$

where $T$ is the temperature in ${ }^{\circ} \mathrm{C}, \delta_{\mathrm{C}}$ is the analyzed isotopic composition of the carbonate sample in per mil relative to the PDB standard, and $\delta_{\mathrm{W}}$ represents the isotopic composition, in per mil, of sea water. In modern normal marine conditions, $\delta_{\mathrm{w}}$ is very close to $-0.27 \%$ (i.e., the $\delta_{W}$ value of the Standard Mean Ocean Water, or SMOW). This value was corrected for local variations in the sea-water isotopic composition by referring to the nearest GEOSECS station 322; Östlund et al., 1987), where the near surface $\delta^{18} \mathrm{O}$ values are on average $0.03 \%$

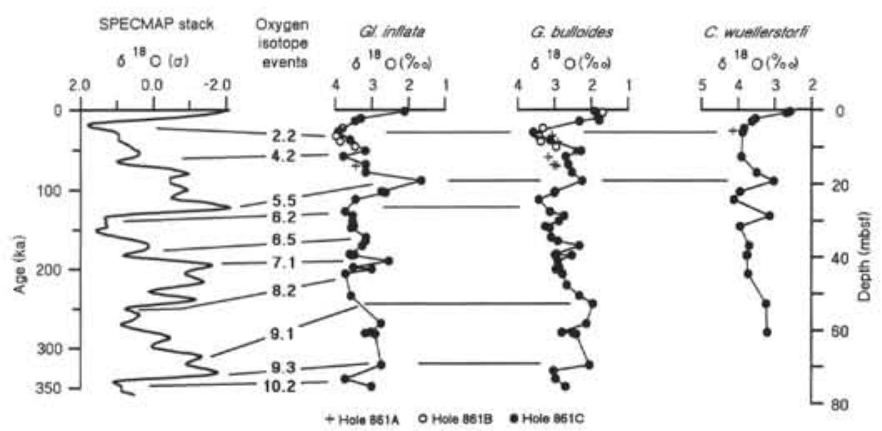

Figure 2. Oxygen isotope curves from ODP Site 861 and correlation of isotope events with the SPECMAP stack (after Imbrie et al., 1984).

versus the SMOW Standard, that is $\delta_{W}=-0.24 \%$. This value was used to calculate recent and Holocene sea-water temperatures.

For the calculation of glacial paleotemperatures with a sea level lowered by about $120 \mathrm{~m}$, a global ice effect on oxygen isotopes of $1.3 \%$ is assumed (Fairbanks, 1989). At the end of Termination Ia, the sea level was $75 \mathrm{~m}$ lower than today (Bard et al., 1989) and thus approximately $61 \%$ of the glacial ice volume was still present. We therefore consider a residual ice-effect of $0.79 \%$ and approximate a $\delta_{\mathrm{W}}$ of $0.52 \%$ for this time based on the $\delta_{\mathrm{w}}$ of SMOW.

Salinity variations due to freshwater influx have also a strong impact on the oxygen isotopic composition of sea water, especially during deglaciations. As the meltwater discharge from Cordilleran glaciers is difficult to estimate and the near-surface water is generally coming from the west, where open ocean conditions prevail, salinity variations are not considered in this paper.

\section{RESULTS}

\section{Carbon Isotopes}

The carbon isotopes of planktonic and benthic foraminifers from Site 861 are given in Figure 3 and Table 3. The values of $G$. bulloides vary between $-1.0 \%$ and $1.3 \%$ while those of $G$. inflata range from $0.0 \%$ to $1.5 \%$. The fluctuations of both curves are similar. For description of the carbon isotope record, we refer to the oxygen isotope stratigraphy as given below.

The variations in the planktonic $\delta^{13} \mathrm{C}$ record fit into a broader, "global" pattern known from other oceans as well. Comparatively high planktonic $\delta^{13} \mathrm{C}$ values during the interglacial Stages 1,5 , and 9 and, in turn, the lower values during the glacial Periods 2, 4, 6, and 8 were reported from the Greenland Sea (Jünger, 1993). Interglacial Stage 7 falls off this pattern at Site 861 and preserves the low $\delta^{13} \mathrm{C}$ level of the preceding glacial Stage 8 . Interestingly, Stage 7 shows also some peculiarities in the Norwegian-Greenland Sea and was termed a "weak" interglacial stage on account of these findings.

High planktonic $\delta^{13} \mathrm{C}$ values of late Stage 5 and the accentuated $\delta^{13} \mathrm{C}$ minimum of Stage 4 are a further well known signature of the $\delta^{13} \mathrm{C}$ records (Jünger and Erlenkeuser, unpubl. data).

The benthic $\delta^{13} \mathrm{C}$ record varies between $-1.0 \%$ and 0.6 . It basically follows the planktonic record but shows, in part, significant phase offsets. Unfortunately, sample spacing does not allow to work out these interesting details with confidence.

\section{Oxygen Isotopes}

The oxygen isotope record of planktonic foraminifers from Site 861 is shown in Figure 2. The values are also given in Table 3. Isotope values of $G$. inflata range from $1.7 \%$ to $4.0 \%$. The graph shows prominent negative excursions near the surface and at $19.10 \mathrm{mbsf}$. Smaller, yet pronounced, $\delta^{18} \mathrm{O}$ minima are located at 41.00 and 58.10 to 69.50 mbsf. The oxygen isotope values of $G$. bulloides range from $1.7 \%$ to $3.7 \%$. Although the fluctuations are very similar to those of $G$. inflata, 

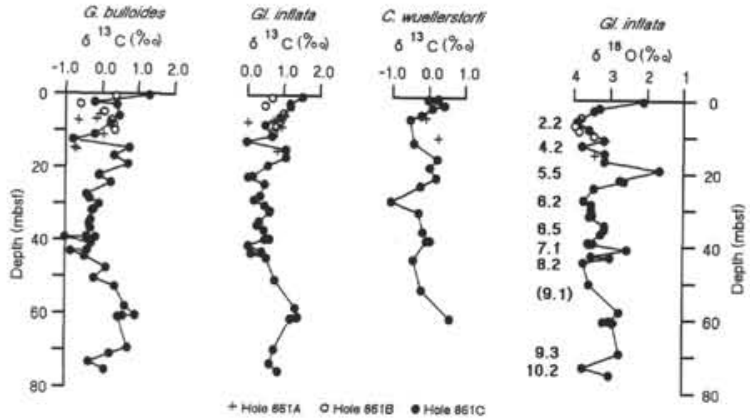

Figure 3. Carbon isotopes from ODP Site 861 . The $\delta^{18} \mathrm{O}$ curve of $G$. inflata and oxygen isotope events are given for comparison.

the full amplitudes of Stages 5 and 7 have either been missed or are not experienced by $G$. bulloides.

The oxygen isotope curve of $G$. inflata is the best developed record. Therefore this curve is mainly referred to for correlation with the SPECMAP stack to assess the age-control points (Fig. 2). Below the near-surface values which represent the Holocene, the first positive excursion at $7.15 \mathrm{mbsf}$ is correlated with the last glacial maximum (i.e., oxygen isotope Event 2.2). This event is also shown by $G$. bulloides and in the benthic record of $C$. wuellerstorfi. Between the Holocene and Event 2.2, the beginning and end of Terminations Ia and $\mathrm{Ib}$ are tentatively indicated in the composite record (Fig. 4). As discussed above, the beginning of Termination $\mathrm{Ib}$ is placed at a $\delta^{18} \mathrm{O}$ level $0.52 \%$ lower than the glacial values.

Below the last glacial maximum, isotope values decrease gradually to the second negative excursion at $19.10 \mathrm{mbsf}$, which is correlated with the last interglacial period (i.e., isotope Event 5.5). This $\delta^{18} \mathrm{O}$ minimum is also seen in the $G$. bulloides and $C$. wuellerstorfi record. Between Events 2.2 and 5.5, additional maxima and minima are recognized and correlated with Events 3.3, 4.2, and 5.1 (Fig. 4). Event 4.2 is well pronounced, and it is also seen in the G. bulloides record. The next positive excursion below Event 5.5 is correlated with the glacial Event 6.2, and the following strong negative excursion represents the interglacial Event 7.1 at 41.00 mbsf.

The correlation of isotopic events is significant down to the level of Event 7.1, but becomes difficult below. As the isotope values increase again to a level as found in the peak glacial Stages 2.2 and 6.2, this subsequent maximum at 44.56 mbsf may represent Stage 8, possibly reveals Event 8.2 . The next two minima reach the level of Event 7.1 and are therefore considered to reflect Events 9.1 and 9.3. The former is also evident in the benthic curve. Event 9.1 is better displayed and therefore defined at the G. bulloides record because of the higher sampling resolution. The next maximum following Event 9.3 is correlated with glacial Event 10.2.

Oxygen isotope values of $G$. inflata indicate equilibrium with near-surface temperatures, although this species evenly inhabits the uppermost $200 \mathrm{~m}$ of the water column (Deuser et al., 1981). G. bulloides lives at shallower depths in near-surface waters but accurately records sea-surface conditions only in a temperature range from $6^{\circ}$ to $14^{\circ} \mathrm{C}$. Shell growth at mean surface temperatures below $6^{\circ} \mathrm{C}$ prefers the summer season and thus leads to $\delta^{18} \mathrm{O}$ values, which are lower than those representing the annual average surface water (Bard et al., 1989). Accordingly, the glacial $\delta^{18} \mathrm{O}$ values of $G$. bulloides may be systematically too low, as the mean annual sea-surface temperature off the coast of southern Chile was only $2^{\circ} \mathrm{C}$ during the last glacial maximum (CLIMAP, 1976). The glacial-interglacial $\delta^{18} \mathrm{O}$ variations of $G$. bulloides show therefore a lower amplitude than those of $G$. inflata.

The benthic oxygen isotope record of $C$. wuellerstorfi varies between $2.6 \%$ and $4.1 \%$. As major features, the low $\delta^{18} \mathrm{O}$ values of the interglacial Stages 1, 5, and 9 are evident. Stage 7 is not shown in the benthic record. The light isotope excursion in the level of Event 6.3
Table 1. Oxygen isotope events, their composite depths in the combined succession at Site 861, ages, and linear sedimentation rates.

\begin{tabular}{crrr}
\hline $\begin{array}{c}\text { Composite } \\
\text { depth } \\
\text { (mbsf) }\end{array}$ & $\begin{array}{c}\text { Oxygen } \\
\text { isotope } \\
\text { event }\end{array}$ & $\begin{array}{c}\text { Age } \\
\text { (ki) }\end{array}$ & $\begin{array}{c}\text { Linear } \\
\text { sedimentation } \\
\text { rate } \\
\text { (cm/k.y.) }\end{array}$ \\
\hline 0.75 & 1.1 & 9.8 & 8.24 \\
2.37 & Ib & 12.4 & 62.31 \\
4.91 & Ia & 18.3 & 43.05 \\
7.15 & 2.2 & 23.5 & 43.08 \\
11.19 & 3.3 & 53.0 & 13.69 \\
12.50 & 4.2 & 65.0 & 10.92 \\
14.70 & 5.1 & 80.0 & 14.67 \\
19.10 & 5.5 & 122.0 & 10.48 \\
27.59 & 6.2 & 135.0 & 65.31 \\
35.50 & 6.5 & 171.0 & 21.97 \\
41.00 & 7.1 & 194.0 & 23.91 \\
44.56 & 8.2 & 249.0 & 6.47 \\
52.80 & 9.1 & 310.0 & 13.50 \\
69.50 & 9.3 & 331.0 & 79.52 \\
73.23 & 10.2 & 341.0 & 37.30 \\
\hline
\end{tabular}

Note: The isotope events are designated according to Prell et al. (1986). Oxygen isotope Events $\mathrm{la}$ and $\mathrm{lb}$ mark the beginning of Terminations $\mathrm{la}$ and $\mathrm{lb}$. Ages of Events 1.1 to 2.2 are based on $\mathrm{Th} / \mathrm{U}$ calibrated radiocarbon ages (after Sarnthein et al.. 1994). whereas the ages of Events 3.3 to 10.2 have been determined by orbital tuning methods (Imbrie et al.. 1984).

Table 2. The occurrence of coarse lithic grains in the upper part of the succession at Leg 141, Site 861 .

\begin{tabular}{|c|c|c|}
\hline $\begin{array}{l}\text { Core, section, } \\
\text { interval }(\mathrm{cm})\end{array}$ & $\begin{array}{c}\text { Composite } \\
\text { depth } \\
\text { (mbsf) }\end{array}$ & $\begin{array}{c}\text { Lithic grains } \\
>500 \mu \mathrm{m} \\
(\%)\end{array}$ \\
\hline $861 \mathrm{C}-1 \mathrm{H}-1,45-49$ & 0.45 & 0 \\
\hline $861 \mathrm{~B}-1 \mathrm{H}-1.75-77$ & 0.75 & 0 \\
\hline $861 \mathrm{C}-1 \mathrm{H}-2,87-92$ & 2.37 & 0 \\
\hline $861 \mathrm{~B}-1 \mathrm{H}-2,131-133$ & 2.81 & 0 \\
\hline $861 \mathrm{C}-1 \mathrm{H}-\mathrm{CC}$ & 3.00 & 0 \\
\hline $861 \mathrm{~B}-1 \mathrm{H}-4,41-43$ & 4.91 & 2.4 \\
\hline 861 A-IH-1. $8-13$ & 5.68 & 0 \\
\hline $861 \mathrm{C}-2 \mathrm{H}-3,9-14$ & 6.09 & 0 \\
\hline $861 \mathrm{~A}-1 \mathrm{H}-1,130-135$ & 6.90 & 0 \\
\hline $861 \mathrm{~B}-1 \mathrm{H}-5,115-117$ & 7.15 & 100.0 \\
\hline $861 \mathrm{~A}-1 \mathrm{H}-2,28-33$ & 7.38 & 40.0 \\
\hline $861 \mathrm{C}-2 \mathrm{H}-4,60-65$ & 8.10 & 0 \\
\hline $861 \mathrm{~B}-1 \mathrm{H}-6,103-106$ & 8.53 & 0 \\
\hline $861 \mathrm{~A}-1 \mathrm{H}-3,9-13$ & 8.69 & 0 \\
\hline $861 \mathrm{~B}-1 \mathrm{H}-\mathrm{CC}$ & 9.90 & 0 \\
\hline $861 \mathrm{C}-2 \mathrm{H}-6,52-57$ & 11.02 & 0 \\
\hline $861 \mathrm{~A}-1 \mathrm{H}-4,109-114$ & 11.19 & 0 \\
\hline $861 \mathrm{C}-2 \mathrm{H}-\mathrm{CC}$ & 12.50 & 4.4 \\
\hline $861 \mathrm{C}-3 \mathrm{H}-2,70-75$ & 14.70 & 0 \\
\hline $861 \mathrm{~A}-1 \mathrm{H}-\mathrm{CC}$ & 15.10 & 0 \\
\hline $861 \mathrm{C}-3 \mathrm{H}-3,13 \mathrm{l}-136$ & 16.81 & 0 \\
\hline $861 \mathrm{C}-3 \mathrm{H}-5,60-65$ & 19.10 & 0 \\
\hline $861 \mathrm{IC}-3 \mathrm{H}-\mathrm{CC}$ & 22.00 & 0 \\
\hline $861 \mathrm{C}-4 \mathrm{H}-1,37-42$ & 22.37 & 0 \\
\hline $861 \mathrm{C}-4 \mathrm{H}-2,70-75$ & 24.20 & 0 \\
\hline $861 \mathrm{C}-4 \mathrm{H}-4,109-114$ & 27.59 & 100.0 \\
\hline $861 \mathrm{C}-4 \mathrm{H}-5,68-73$ & 28.68 & 0 \\
\hline
\end{tabular}

Note: The portion of lithic grains is expressed in percent related to the total number of lithic and biogenic particles.

parallels a similar response in the planktonic record of $G$. bulloides. On the whole, however, the benthic isotope record suffers greatly from poor sample coverage.

\section{Age Model}

The ages of isotope events are plotted against depth in Figure 5. The age-depth curve suggests a continuous sedimentation. Two changes in slope occur at 7.15 and $19.10 \mathrm{mbsf}$, and another prominent break in slope at $52.80 \mathrm{mbsf}$. Even though the data resolution is comparatively low in the lower part of the section studied, the age-depth curve indicates no larger hiatus in the uppermost 73 mbsf at Site 861 . 
Table 3. Oxygen and carbon isotopes from Site 861 .

\begin{tabular}{|c|c|c|c|c|c|c|c|c|}
\hline \multirow[b]{2}{*}{$\begin{array}{l}\text { Core, section, } \\
\text { interval }(\mathrm{cm})\end{array}$} & \multirow[b]{2}{*}{$\begin{array}{l}\text { Depth } \\
\text { (mbsf) }\end{array}$} & \multirow[b]{2}{*}{$\begin{array}{c}\text { Composite depth } \\
\text { (mbsf) }\end{array}$} & \multicolumn{2}{|c|}{ Globigerina bulloides } & \multicolumn{2}{|c|}{ Globoconella inflata } & \multicolumn{2}{|c|}{ Cibicidoides wuellerstorfi } \\
\hline & & & $\begin{array}{l}\delta^{13} \mathrm{C} \\
(\% c)\end{array}$ & $\begin{array}{l}\delta^{18} \mathrm{O} \\
(\% c)\end{array}$ & $\begin{array}{l}\delta^{13} \mathrm{C} \\
(\% 6)\end{array}$ & $\begin{array}{l}\delta^{18} \mathrm{O} \\
(\% c)\end{array}$ & $\begin{array}{l}\delta^{13} \mathrm{C} \\
(\%)\end{array}$ & $\begin{array}{l}\delta^{18} \mathrm{O} \\
(\% \circ)\end{array}$ \\
\hline $\begin{array}{l}141-861 \mathrm{~A}- \\
1 \mathrm{H}-1,8-13\end{array}$ & 0.08 & & & & & 3.84 & & \\
\hline $1 \mathrm{H}-1,130-135$ & $\begin{array}{l}0.08 \\
1.30\end{array}$ & $\begin{array}{l}5.68 \\
6.90\end{array}$ & $\begin{array}{l}-0.07 \\
-0.16\end{array}$ & $\begin{array}{l}2.54 \\
3.07\end{array}$ & $\begin{array}{l}1.04 \\
0.71\end{array}$ & $\begin{array}{l}3.84 \\
3.85\end{array}$ & -0.09 & $\underline{4.14}$ \\
\hline $\mathrm{IH}-2,28-33$ & 1.78 & 7.38 & -0.65 & 3.49 & 0.01 & 3.86 & - & - \\
\hline $1 \mathrm{H}-3,9-13$ & 3.09 & 8.69 & 0.23 & 2.91 & 0.93 & 3.57 & - & - \\
\hline $1 \mathrm{H}-4,109-114$ & 5.59 & 11.19 & 0.03 & 2.40 & 0.72 & 3.16 & 0.25 & 2.19 \\
\hline IH-5, $118-123$ & 7.18 & 12.78 & -2.09 & 3.17 & - & - & - & - \\
\hline $1 \mathrm{H}-7,20-25$ & 9.20 & 14.80 & -0.76 & 3.02 & - & - & - & - \\
\hline IH-CC & 9.50 & 15.10 & -0.70 & 2.93 & 0.82 & 3.44 & - & - \\
\hline 141-861B- & & & & & & & & \\
\hline $1 \mathrm{H}-1,75-77$ & 0.75 & 0.75 & 0.38 & 1.69 & 0.68 & 1.92 & -0.03 & 2.69 \\
\hline $1 \mathrm{H}-2,131-133$ & 2.81 & 2.81 & -0.59 & 1.78 & 0.48 & 2.35 & - & - \\
\hline IH $-4,41-43$ & 4.91 & 4.91 & 0.05 & 3.32 & 0.99 & 3.81 & -0.22 & 3.84 \\
\hline $1 \mathrm{H}-5,115-117$ & 7.15 & 7.15 & 0.27 & 3.43 & 0.89 & 3.98 & - & - \\
\hline $1 \mathrm{H}-6,103-106$ & 8.53 & 8.53 & 0.32 & 3.38 & 0.78 & 3.87 & - & - \\
\hline $\mathrm{IH}-\mathrm{CC}$ & 9.90 & 9.90 & 0.35 & 2.96 & 0.71 & 3.46 & - & - \\
\hline $141-861 \mathrm{C}-$ & & & & & & & & \\
\hline IH-1, $45-49$ & 0.45 & 0.45 & 1.30 & 1.91 & 1.51 & 2.10 & 0.25 & 2.59 \\
\hline $1 \mathrm{H}-2,87-92$ & 2.37 & 2.37 & -0.21 & 1.81 & 1.17 & 3.31 & 0.42 & 3.53 \\
\hline $\mathrm{IH}-\mathrm{CC}$ & 3.00 & 3.00 & 0.40 & 2.32 & 1.19 & 3.46 & 0.10 & 3.62 \\
\hline $2 \mathrm{H}-3,9-14$ & 6.09 & 6.09 & 0.48 & 3.58 & 0.89 & 3.92 & -0.52 & 3.88 \\
\hline $2 \mathrm{H}-4,60-65$ & 8.10 & 8.10 & 0.23 & 3.12 & 0.48 & 3.60 & - & - \\
\hline $2 \mathrm{H}-6,52-57$ & 11.02 & 11.02 & -0.21 & 2.28 & 0.67 & 3.19 & - & - \\
\hline $2 \mathrm{H}-\mathrm{CC}$ & 12.50 & 12.50 & -0.80 & 2.70 & -0.04 & 3.78 & -0.42 & 3.90 \\
\hline $3 \mathrm{H}-2,70-75$ & 14.70 & 14.70 & 0.75 & 2.63 & 1.05 & 3.17 & 0.75 & 3.17 \\
\hline $3 \mathrm{H}-3,13 \mathrm{I}-136$ & 16.81 & 16.81 & 0.33 & 2.53 & 1.05 & 3.17 & 0.23 & 3.50 \\
\hline $3 \mathrm{H}-5,60-65$ & 19.10 & 19.10 & 0.73 & 2.25 & 0.57 & 1.65 & 0.03 & 3.03 \\
\hline $3 \mathrm{H}-\mathrm{CC}$ & 22.00 & 22.00 & -0.06 & 2.98 & 0.15 & 2.74 & 0.21 & 3.94 \\
\hline $4 \mathrm{H}-1,37-42$ & 22.37 & 22.37 & -0.08 & 3.00 & 0.02 & 2.63 & -0.31 & 2.99 \\
\hline $4 \mathrm{H}-2,70-75$ & 24.20 & 24.20 & 0.25 & 3.42 & 0.48 & 3.45 & -0.23 & 4.11 \\
\hline $4 \mathrm{H}-4,109-114$ & 27.59 & 27.59 & -0.42 & 3.11 & 0.35 & 3.73 & - & - \\
\hline $4 \mathrm{H}-5,68-73$ & 28.68 & 28.68 & -0.34 & 2.74 & 0.19 & 3.52 & -1.03 & 3.14 \\
\hline $4 \mathrm{H}-6,66-71$ & 30.16 & 30.16 & -0.08 & 2.88 & 0.48 & 3.53 & - & - \\
\hline $4 \mathrm{H}-\mathrm{CC}$ & 31.50 & 31.50 & -0.22 & 3.25 & 0.63 & 3.49 & -0.28 & 3.94 \\
\hline $5 \mathrm{H}-2,10-12$ & 31.90 & 31.90 & -0.27 & 3.13 & 0.62 & 3.57 & - & - \\
\hline $5 \mathrm{H}-3,129-131$ & 34.59 & 34.59 & -0.31 & 3.10 & 0.33 & 3.16 & - & - \\
\hline $5 \mathrm{H}-4,70-72$ & 35.50 & 35.50 & -0.35 & 2.90 & 0.27 & 3.17 & - & - \\
\hline $5 \mathrm{H}-5,59-6 \mathrm{I}$ & 36.89 & 36.89 & -0.32 & 2.32 & 0.46 & 3.26 & -0.17 & 3.69 \\
\hline $5 \mathrm{H}-6,130-132$ & 39.10 & 39.10 & -0.43 & 2.94 & 0.54 & 3.60 & - & - \\
\hline $5 \mathrm{H}-7,5-7$ & 39.35 & 39.35 & -0.18 & 2.98 & 0.62 & 3.48 & 0.04 & 3.74 \\
\hline $5 \mathrm{H}-7,10-12$ & 39.40 & 39.40 & -1.02 & 2.53 & 0.48 & 3.56 & -0.07 & 3.76 \\
\hline $5 \mathrm{H}-\mathrm{CC}$ & 41.00 & 41.00 & -0.30 & 2.90 & 0.03 & 2.53 & - & - \\
\hline $6 \mathrm{H}-2,38-42$ & 42.88 & 42.88 & -0.39 & 2.87 & 0.41 & 3.51 & -0.31 & 3.80 \\
\hline $6 \mathrm{H}-2,77-81$ & 43.27 & 43.27 & -0.85 & 2.96 & 0.12 & 3.00 & - & - \\
\hline $6 \mathrm{H}-3,56-60$ & 44.56 & 44.56 & -0.46 & 2.78 & 0.54 & 3.72 & -0.41 & 3.72 \\
\hline $6 \mathrm{H}-5,67-7 \mathrm{I}$ & 47.67 & 47.67 & 0.12 & 2.66 & - & - & - & - \\
\hline $6 \mathrm{H}-\mathrm{CC}$ & 50.50 & 50.50 & -0.21 & 2.31 & 0.78 & 3.57 & - & - \\
\hline $7 \mathrm{H}-3,39-44$ & 52.80 & 52.80 & 0.37 & 1.94 & - & - & -0.19 & 3.23 \\
\hline $7 \mathrm{H}-6,10-15$ & 58.10 & 58.10 & 0.65 & 2.13 & 1.35 & 2.75 & - & - \\
\hline $7 \mathrm{H}-7,109-111$ & 60.59 & 60.59 & 0.94 & 2.80 & 1.41 & 3.02 & 0.60 & 3.20 \\
\hline $7 \mathrm{H}-7,124-129$ & 60.74 & 60.74 & 0.59 & 2.49 & 1.37 & 3.18 & - & - \\
\hline $7 \mathrm{H}-\mathrm{CC}$ & 61.00 & 61.00 & 0.45 & 2.40 & 1.20 & 2.91 & - & - \\
\hline $8 \mathrm{H}-\mathrm{CC}$ & 69.50 & 69.50 & 0.74 & 2.04 & 0.76 & 2.74 & - & - \\
\hline $9 \mathrm{H}-\mathrm{CC}$ & 71.00 & 71.00 & 0.24 & 3.03 & 1.09 & 0.78 & - & - \\
\hline $10 \mathrm{H}-2,73-78$ & 73.23 & 73.23 & -0.34 & 2.97 & 0.64 & 3.73 & - & - \\
\hline $10 \mathrm{H}-3,131-136$ & 75.31 & 75.31 & 0.10 & 2.70 & 0.87 & 3.01 & - & - \\
\hline
\end{tabular}

\section{Sedimentation Rates}

Linear sedimentation rates calculated between age-control points are given in Table 1 . They vary between 8 and $14 \mathrm{~cm} / \mathrm{k} . y$. during interglacial periods and range from 21 to $43 \mathrm{~cm} / \mathrm{k} . \mathrm{y}$. during glacial periods. The sedimentation rates were even higher during Terminations I and II, when they reached $65 \mathrm{~cm} / \mathrm{k}$.y. These high rates may be the result of enhanced meltwater discharge from the Cordilleran glaciers and thus increased fluxes of fine-grained suspension during deglaciation periods.

In the interval between 41.00 and 44.56 mbsf, the sedimentation rate of $6 \mathrm{~cm} / \mathrm{k}$.y. is extraordinary low. This interval coincides with the top of lithostratigraphic Subunit II which is marked by the highest occurrence of debris-flow sediments. It is therefore most likely, that the debris flows eroded significant amounts of sediment at the location of Site 861 which results, on average, in a comparatively low sedimentation rate for this interval.

In the section below 44.56 mbsf, sedimentation rates are similar as above $41 \mathrm{mbsf}$ and vary between 14 and $80 \mathrm{~cm} / \mathrm{k} . \mathrm{y}$. The highest rate is recorded between oxygen isotope Events 9.1 and 9.3 at 52.80 and $69.50 \mathrm{mbsf}$, respectively. As that interval belongs to the warm Stage 9 of the climatic record, meltwater discharge from Cordilleran glaciers cannot account for this high sedimentation rate. Thick, graded beds of silty sand, probably turbidites, were recovered from 53.70 to 60.00 mbsf (Shipboard Scientific Party, 1992). If their thickness is subtracted from the interval between isotope Events 9.1 and 9.3 , the remaining sedimentation rate of $50 \mathrm{~cm} / \mathrm{k} . \mathrm{y}$. is in the range of values from Subunit I though still too high for an interglacial period. The extraordinary high sedimentation rate between 52.80 and 69.50 mbsf may therefore result from the sand-turbidite deposition superimposed on the normal background sedimentation.

\section{Ice-rafted Debris}

Coarse lithic grains were found in samples from $4.91 \mathrm{mbsf}$, the beginning of Termination Ia; 7.15 mbsf, the last glacial maximum; $12.50 \mathrm{mbsf}$, at the level of Event 4.2 corresponding to an accentuated glacial phase; and at $27.59 \mathrm{mbsf}$, the level of Event 6.2 representing 


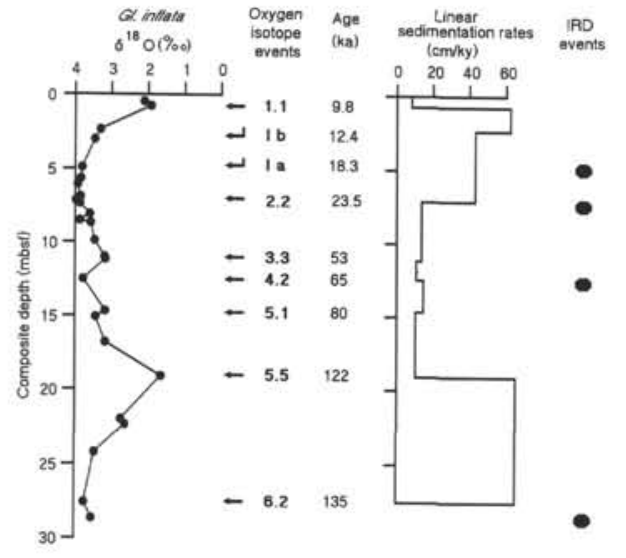

Figure 4. Composite oxygen isotope record of Globoconella inflata, agecontrol points, linear sedimentation rates, and occurrences of ice-rafted debris (IRD) at Site 861. Oxygen isotope Events Ia and Ib mark the beginning of Terminations la and Ib.

the previous glacial period (Fig. 4). The sample spacing is too wide to constrain the levels precisely where coarse lithic grains occur. The composite section spanning the last glacial maximum reveals, however, that coarse lithic fragments occur only in a distinct, 0.23 to 1.20 $\mathrm{m}$ thick interval which covers oxygen isotope Event 2.2 (Table 2).

These levels with coarse lithic grains do not coincide with scarce, thin beds of fine sand. Hence it is unlikely that the coarse lithic fragments were transported by gravity-driven downslope-transport processes (e.g., Bein and Fütterer, 1977). The lithic grains are therefore interpreted as dropstones (Kudrass, 1973). As their occurrence falls into cool or glacial intervals of the climatic record, the coarse grains indicate ice-rafting during these periods. They do not necessarily correlate with or precede periods with high sedimentation rates (Fig. 4). Therefore, ice rafting did not enhance the fine-grained pelagic fallout significantly. The restricted occurrence of coarse lithic grains during the last glacial maximum suggests, that ice-rafting only took place at peak glacials and is not associated with climatic changes (i.e., deglaciations). The ice came most likely from the Cordilleran glaciers which extended beyond the shelf edge off the coast of southern Chile during the last glaciation (Fischer, 1974).

\section{Paleotemperature Implications}

Surface-water paleotemperatures are deduced from the oxygen isotopic composition of $G$. bulloides. This species lives below the thermocline but ascends for reproduction into the near-surface mixed layer, where most of the test calcifies (Kahn and Williams, 1981). G. bulloides is therefore considered to record sea-surface conditions, though only in a temperature range from $6^{\circ}$ to $14^{\circ} \mathrm{C}$ (Bard et al., 1989). $G$. inflata evenly inhabits the uppermost $200 \mathrm{~m}$ of the water column and thus lives above and below the thermocline. Oxygen isotope values indicate, however, equilibrium with near-surface temperatures (Deuser et al., 1981), but it is unknown, at which depth the test of $G$. inflata calcifies.

Holocene $\delta^{18} \mathrm{O}$-values of $G$. bulloides are on average $1.80 \%$ at Site 861. Applying the temperature equation of Craig (1965) and assuming $\delta_{\mathrm{w}}=-0.24 \%$, as considered above, a mean sea-surface temperature of $8^{\circ} \mathrm{C}$ is calculated. This estimate is slightly lower but very close to the range of the present seasonal temperature variations in the surface waters off the coast of southern Chile (i.e., $9^{\circ}$ to $13^{\circ} \mathrm{C}$; Boltovskoy, 1976).

At Site $861, G$. bulloides tests reveal a $\delta^{18} \mathrm{O}$ of $2.32 \%$ in the interval where subtropical planktonic foraminifers are recorded (Section 141-861C-1H-CC). As this level corresponds to the end of Termination Ia, an ice-effect corrected $\delta_{\mathrm{W}}$ of $0.52 \%$ is assumed and the

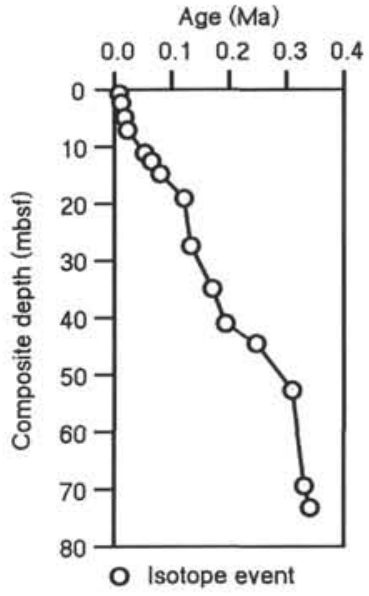

Figure 5. Age model of the isotope record from Site 861. Ages are given in million years for better comparability with other age-depth curves in the Proceedings of the Ocean Drilling Program.

paleotemperature is calculated as above. The resulting sea-surface temperature of $9^{\circ} \mathrm{C}$ demonstrates, that this site was not under the influence of the warm-water sphere. This temperature is far too low for subtropical planktonic foraminifers. Nevertheless, Beella digitata and Neogloboquadrina dutertrei did appear in the sample interval. $N$. dutertrei only tolerates temperatures that are higher than $13^{\circ} \mathrm{C}$ (Hemleben et al., 1989) whereas B. digitata usually occurs in areas where the annual average temperature exceeds $20^{\circ} \mathrm{C}$ (Barash, 1992).

A possible explanation for this puzzling discrepancy is that the subtropical assemblage of planktonic foraminifers drifted with a Kelvin wave carrying warm surface water to the location of Site 861. On El Niño events, Kelvin waves of western Pacific warm water move to the west coast of South America and split near the Equator into two poleward-travelling coastal Kelvin waves. Although the influence of the northern branch is recognized up to the United States coast of Washington (Pickard and Emery, 1993), the southern branch usually proceeds southward only to $20^{\circ} \mathrm{S}$ (Bigg, 1990). Our results therefore suggest that the Kelvin waves may have proceeded even farther southward during the end of Termination Ia. The warm-water masses transported during these events may have had a strong impact on the local climate in southern Chile. Mercer (1970) found that the glaciers within the Cordilleras were even smaller by $11,000 \mathrm{yr}\left({ }^{14} \mathrm{C}\right.$ time scale, which resembles $13 \mathrm{ka}$ on the calendar time scale) than they are at present.

\section{SUMMARY}

Stable carbon and oxygen isotopes were analyzed from the planktonic foraminifers $G$. bulloides and $G$. inflata and the epibenthic species $C$. wuellerstorfi from the uppermost $80 \mathrm{mbsf}$ of ODP Site 861. Oxygen isotope stratigraphy was applied as chronostratigraphic tool to develop an age model and to calculate sedimentation rates.

Carbon isotopes of planktonic foraminifers show climatic fluctuations similar as the $\delta^{18} \mathrm{O}$ curves. Glacial intervals generally reveal low $\delta^{13} \mathrm{C}$ values, and low $\delta^{18} \mathrm{O}$ levels during interglacial periods correspond to high $\delta^{13} \mathrm{C}$ values.

The oxygen isotope record of $G$. inflata shows the most detailed affinity to the SPECMAP stack and is therefore used to assess the age-control points. Most of the isotope events from the stacked curve could be clearly identified down to $41 \mathrm{mbsf}$ at Site 861 . The $\delta^{18} \mathrm{O}$ curve of $G$. inflata reveals in combination with that of $G$. bulloides, however, that the record extends back to oxygen isotope Event 10.2 of $341 \mathrm{ka}$.

The age-depth curve reveals a continuous sedimentation with three major changes in sedimentation rate. Despite the low data resolution in the lower part of the section studied, the age-depth curve indicates no larger hiatus in the uppermost 73 mbsf at Site 861. 
Linear sedimentation rates vary between 6 and $80 \mathrm{~cm} / \mathrm{k} . \mathrm{y}$. In the lithostratigraphic Subunit I above 41 mbsf, sedimentation rates are highest during Terminations I and II. The high rates during deglaciation periods are most likely caused by extended sediment-laden plumes of turbid melt water discharged from the Cordilleran glaciers. In the upper part of Subunit II, sedimentation rates are generally lower than in Subunit I. The highest rate of $80 \mathrm{~cm} / \mathrm{k} . \mathrm{y}$. is recorded, however, between 52.80 and $69.50 \mathrm{mbsf}$, where massive sand turbidites occur. The high sedimentation rate in this interval may therefore result from turbidite deposition superimposed on the background sedimentation.

Large lithic grains of ice-rafted debris are recorded only in four distinct intervals that resemble cool or glacial intervals of the climatic record. This indicates an advance of the Cordilleran glaciers to the sea, with extended ice rafting during these periods. Episodes with ice rafting do not match with periods of high sedimentation rates.

An isotopic sea-surface paleotemperature of $9^{\circ} \mathrm{C}$ is calculated for an interval at the end of Termination Ia from which subtropical planktonic foraminifers were recorded. These forms tolerate, however, only temperatures higher than $13^{\circ} \mathrm{C}$. We conclude that the occurrence of the subtropical assemblage of planktonic foraminifers is indicative of a Kelvin wave of warm surface water drifted to Site 861 as an effect of strong El Niño events. This warm water transport has also been proposed by Locker (this volume) on the evidence from silicoflagellate assemblages.

\section{REFERENCES}

Barash, M.S., 1992. Cenozoic paleoceanography based on micropalaeontological data: methods and results. Fourth Int. Conf. Paleoceanography Abstr. Programs, 51-52.

Bard, E., Arnold, M., Maurice, P., Duprat, J., Moyes, J., and Duplessy, J.-C., 1987. Retreat velocity of the North Atlantic polar front during the last deglaciation determined by ${ }^{14} \mathrm{C}$ accelerator mass spectrometry. Nature, 328:791-794

Bard, E., Fairbanks, R., Arnold, M., Maurice, P., Duprat, J., Moyes, J., and Duplessy, J.-C., 1989. Sea-level estimates during the last deglaciation based on $\delta^{18} \mathrm{O}$ and accelerator mass spectrometry ${ }^{14} \mathrm{C}$ ages measured in Globigerina bulloides. Quat. Res., 31:381-391.

Bein, A., and Fütterer, D., 1977. Texture and composition of continental shelf to rise sediments off the northwestern coast of Africa: an indication for downslope transportation. "Meteor" Forschungsergeb. Reihe C, 27:46-74.

Bigg, G.R., 1990. El Niño and the Southern Oscillation. Weather, 45:2-8.

Boltovskoy, E., 1976. Distribution of Recent foraminifera of the South American region. In Hedley, R.H., and Adams, C.G. (Eds.), Foraminifera (Vol. 2): London (Academic Press), 171-237.

Broecker, W.S., Andree, M., Wölfli, W., Oeschger, H., Bonani, G., Kennett, J.P., and Peteet, D., 1988. The chronology of the last deglaciation: implications to the cause of the Younger Dryas event. Paleoceanography, $3: 1-19$.

CLIMAP Project Members, 1976. The surface of the ice-age Earth. Science, 191:1131-1137.

Couper, A., 1989. The Times Atlas and Encyclopedia of the Sea: London (Times Books).

Craig, H., 1957. Isotopic standards for carbon and oxygen and correction factors for mass spectrometric analysis of $\mathrm{CO}_{2}$. Geochim. Cosmochim. Acta, 12:133-149.

-1965. The measurement of oxygen isotope paleotemperatures. In Tongiorgi, E. (Ed.), Stable Isotopes in Oceanographic Studies and Paleotemperatures, Spoleto, 1965: Pisa (Consiglio Nazionale delle Ricerche, Laboratorio di Geologia Nucleare), 161-182.
Deuser, W.G., Ross, E.H., Hemleben, C., and Spindler, M., 1981. Seasonal changes in species composition numbers, mass, size and isotopic composition of planktonic foraminifera settling into the deep Sargasso Sea. Palaeogeogr., Palaeoclimatol., Palaeoecol., 33:103-127.

Duplessy, J.-C., Arnold, M., Maurice, P., Bard, E., Duprat, J., and Moyes, J., 1986. Direct dating of the oxygen-isotope record of the last deglaciation by ${ }^{14} \mathrm{C}$ accelerator mass spectrometry. Nature, 320:350-352.

Fairbanks, R.G., 1989. A 17,000-year glacio-eustatic sea level record: influence of glacial melting rates on the Younger Dryas event and deep-ocean circulation. Nature, 342:637-642.

Fischer, K., 1974. Die pleistozäne Vergletscherung und die Frage der Landsenkung im Bereich des Chonos-Archipels, Südchile. Eiszeitalter Ggw. 25:126-131.

Hemleben, C., Spindler, M., and Anderson, O.R., 1989. Modern Planktonic Foraminifera: New York (Springer).

Imbrie, J., Shackleton, N.J., Pisias, N.G., Morley, J.J., Prell, W.L., Martinson, D.G., Hays, J.D., McIntyre, A., and Mix, A.C., 1984. The orbital theory of Pleistocene climate: support from a revised chronology of the marine $\delta^{18} \mathrm{O}$ record. In Berger, A.L., Imbrie, J., Hays, J., Kukla, G., and Saltzman, B. (Eds.), Milankovitch and Climate (Pt. 2): Dordrecht (D. Reidel), 269-305.

Jünger, B., 1993. Tiefwassererneuerung in der Grönlandsee während der letzten 340,000 Jahre [Ph.D. dissert.]. Christian-Albrechts-Univ., Kiel, Germany.

Kahn, M.I., and Williams, D.F., 1981. Oxygen and carbon isotopic composition of living planktonic foraminifers from the northeast Pacific Ocean. Palaeogeogr., Palaeoclimatol., Palaeoecol., 33:47-69.

Kudrass, H.R., 1973. Sedimentation am Kontinentalhang vor Portugal und Marokko im Spätpleistozän und Holozän. "Meteor" Forschungsergeb., Reihe C, 13:1-63.

Mercer, J.H., 1970. Variations of some Patagonian glaciers since the Late Glacial: II. Science, 269:1-25.

Östlund, H.G., Craig, H., Broecker, W.S., and Spencer, D. (Eds.), 1987. GEOSECS Atlantic, Pacific, and Indian Ocean expeditions. Geosecs Atlas Series (Vol. 7): Washington (U.S. Govt. Printing Office).

Pickard, G.L., and Emery, W.J., 1993. Descriptive Physical Oceanography: an Introduction (6th ed.): Oxford (Pergamon).

Pisias, N.G., Martinson, D.G., Moore, T.C., Shackleton, N.J., Prell, W., Hays, J., and Boden, G., 1984. High resolution stratigraphic correlation of benthic oxygen isotopic records spanning the last 300,000 years. Mar. Geol., 56:119-136.

Prell, W.L., Imbrie, J., Martinson, D.G., Morley, J.J., Pisias, N.G., Shackleton, N.J., and Streeter, H.F., 1986. Graphic correlation of oxygen isotope stratigraphy: application to the late Quaternary. Paleoceanography, 1:137-162.

Sarnthein, M., and Tiedemann, R., 1990. Younger Dryas-Style cooling events at glacial terminations I-VI at ODP Site 658: associated benthic $\delta^{13} \mathrm{C}$ anomalies constrain meltwater hypothesis. Paleoceanography, 5:10411055.

Sarnthein, M., Winn, K., Jung, S., Duplessy, J.C., Labeyrie, L., Erlenkeuser. H., and Ganssen, G., 1994. Changes in East Atlantic deep-water circulation over the last 30,000 years: Eight-time-slice reconstructions. Paleoceanography, 9:209-267.

Shipboard Scientific Party, 1992. Site 861. In Behrmann, J.H., Lewis, S.D., Musgrave, R.J., et al., Proc. ODP, Init. Repts., 141: College Station, TX (Ocean Drilling Program), 239-299.

\footnotetext{
Abbreviations for names of organizations and publications in ODP reference lists follow the style given in Chemical Abstracts Service Source Index (published by American Chemical Society).
}

\author{
Date of initial receipt: 13 October 1993 \\ Date of acceptance: 29 July 1994 \\ Ms 141SR-044
}

